Check for updates

Cite this: RSC Adv., 2017, 7, 42013

Received 4th July 2017

Accepted 24th August 2017

DOI: 10.1039/c7ra07379h

rsc.li/rsc-advances

\section{Bis-tridentate Ru(II) sensitizers with a spatially encumbered 2,6-dipyrazolylpyridine ancillary ligand for dye-sensitized solar cells $\uparrow$}

\begin{abstract}
Ting-Kuang Chang and Yun Chi (iD)*

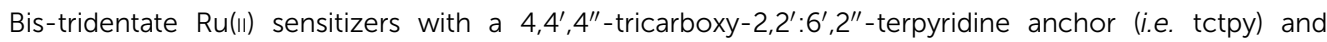
a 2,6-dipyrazolyl pyridine ancillary ligand with either 5-dodecylthien-2-yl or t-butyl substituents at the central pyridyl unit and four distinctive perfluoroalkyl fragments (e.g. $\mathrm{CF}_{3}, \mathrm{C}_{3} \mathrm{~F}_{7}, \mathrm{C}_{5} \mathrm{~F}_{11}$ and $\mathrm{C}_{7} \mathrm{~F}_{15}$ ) at the terminal pyrazolyl sites were designed, synthesized and applied as sensitizers for the fabrication of dyesensitized solar cells. All these sensitizers exhibited suitable optical properties and electrochemical characteristics. In addition, despite the TF-tBu series of sensitizers with $t$-butyl substituents showing a lowered absorption extinction coefficient vs. their 5-dodecylthien-2-yl substituted counterparts (i.e. TF-2' series) in solution, their smaller molecular size allowed a larger dye loading on $\mathrm{TiO}_{2}$ photoanodes, which offsets the inferior optical response and makes them the better DSC sensitizers. After appropriate selection of $\mathrm{C}_{3} \mathrm{~F}_{7}$ substituents, the sensitizer coded TF- $t \mathrm{Bu} \mathrm{C}_{3} \mathrm{~F}_{7}$ showed the highest overall efficiencies of $J_{S C}=18.47 \mathrm{~mA} \mathrm{~cm}^{-2}, V_{O C}=767 \mathrm{mV}, \mathrm{FF}=0.71$ and $\mathrm{PCE}=10.05 \%$ under simulated one sun irradiation, due to the fine balance between dye loading and reduced charge recombination. The corresponding enlarged solar cell module with an active area of $11.2 \mathrm{~cm}^{2}$ also showed the best PCE of 7.55\% under one sun irradiation with PCE reaching $12.70 \%$ under T5 lighting at 2400 lux.
\end{abstract}

\section{Introduction}

Dye sensitized solar cells (DSC) have attracted considerable research attention as a possible replacement for commercial silicon based photovoltaics due to the lower fabrication costs and versatility in making flexible devices. ${ }^{1-7}$ DSC are composed of three compartments: (i) a layer of $\mathrm{TiO}_{2}$ nanoparticles with the deposited light-harvesting sensitizers which enable injection of photoelectrons, ${ }^{8}$ (ii) an electrolyte containing a suitable redox couple (most commonly $\mathrm{I}_{3}{ }^{-} / \mathrm{I}^{-}$) for regeneration of the oxidized sensitizers, ${ }^{9}$ and (iii) a counter electrode (or cathode) to reduce the oxidized component of the electrolyte to complete the carrier flux. ${ }^{10}$ Sensitizers constitute one key challenge in the development of efficient and stable DSC devices. Despite having many adequate precedents, such as: $\mathrm{Ru}(\mathrm{II})$ thiocyanate and azolate complexes, ${ }^{11-14}$ zinc porphyrins, ${ }^{15-18}$ and even organic dyes with push-pull charge transfer characteristics, ${ }^{19-22}$ they are still not satisfactory because of the poor device longevity, particular they require introduction of a co-adsorbent to suppress aggregation of the sensitizers on the $\mathrm{TiO}_{2}$ surface for increasing the $V_{\text {OC }}$.

Department of Chemistry, Low Carbon Energy Research Center, National Tsing Hua University, Hsinchu 30013, Taiwan. E-mail: ychi@mx.nthu.edu.tw

$\dagger$ Electronic supplementary information (ESI) available. See DOI: 10.1039/c7ra07379h
Amid various DSC sensitizers, Ru(II) complexes are probably the best design that showed better compromise between device efficiency and stability. ${ }^{23-25}$ They were reported to achieve high power conversion efficiency (PCE) of over $11.5 \%$ with the employment of sensitizers N749 (ref. 26 and 27) and PRT-22, ${ }^{28}$ independently. Both sensitizers possess $4,4^{\prime}, 4^{\prime \prime}$-tricarboxy$2,2^{\prime}: 6^{\prime}, 2^{\prime \prime}$-terpyridine anchoring chelate (i.e. tctpy) and at least one thiocyanate ancillary ( $c f$. Scheme 1$)$. Due to the possession of three carboxy anchors in tctpy chelate, these Ru(II) sensitizers have exhibited a further red-shifted absorption onsets versus the $\mathrm{Ru}(\mathrm{II})$ sensitizers with the alternative $4,4^{\prime}$-dicarboxy-2,2'-bipyridine anchor (i.e. dcbpy), as shown in N719, C101 and etc. Notably, DSC fabricated with the dcbpy based Ru(II) sensitizers are also capable to exhibit high PCE of $\sim 11.1 \%,{ }^{29}$ but their relative performances are still inferior to that of tctpy based $\mathrm{Ru}(\mathrm{II})$ sensitizers due to the reduced $\pi$-conjugation of dcbpy that caused higher onset energy for light absorption.

Furthermore, the performance of these Ru(II) based DSC devices, particularly the longevity, is known to depend on their intrinsic molecular structure, which can be improved by removal of thiocyanate ancillaries and replaced them with a dianionic tridentate ancillary in addition to the tctpy anchor. These so-called bis-tridentate sensitizers possess two tridentate chelates (one with carboxy-containing anchor), ${ }^{30-34}$ for which the dye molecules are expected to be more stable than those bearing monodentate thiocyanate ${ }^{35-37}$ and even the alternative $\mathrm{Ru}(\mathrm{II})$ sensitizers with tris-heteroleptic or tris-bidentate 


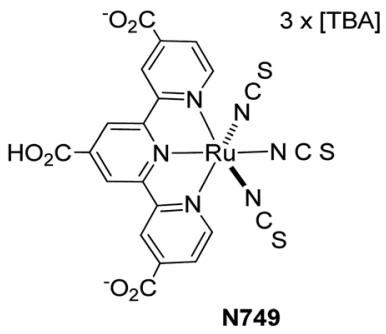

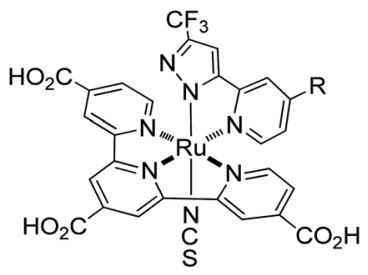

PRT-22, R = 5-(hexylthio)thien-2-yl

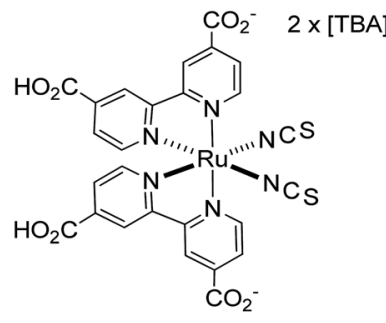

N719

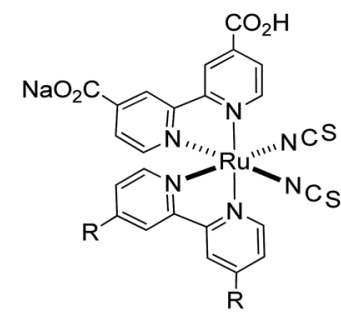

C101, R = 5-hexylthien-2-yl

Scheme 1 Structural drawings of Ru(II) sensitizers N749, PRT-22, N719 and C101.

architecture, ${ }^{38-41}$ from the view point of entropy. In view of this, we proceed to optimize the TF-series of $\mathrm{Ru}(\mathrm{II})$ sensitizers, namely: TF- $2, \mathrm{TF}-2^{\prime}$ and $\mathrm{TF}-\mathrm{Bu}$ by attachment of distinctive alkyl group $\left(\mathrm{R}=\mathrm{C}_{6} \mathrm{H}_{13}\right.$ and $\left.\mathrm{C}_{12} \mathrm{H}_{25}\right)$ and perfluoroalkyl group $\left(\mathrm{R}^{\mathrm{F}}=\mathrm{CF}_{3}, \mathrm{C}_{3} \mathrm{~F}_{7}, \mathrm{C}_{5} \mathrm{~F}_{11}\right.$ and $\left.\mathrm{C}_{7} \mathrm{~F}_{15}\right)$ at the azolyl fragments of the 2,6-dipyrazolyl pyridine ancillary, for which the abbreviations TF-2, TF- $2^{\prime}$ and TF- $t$ Bu stand for the bis-tridentate Ru(II) sensitizers substituted with 5-hexylthien-2-yl, 5-dodecylthien-2-yl and $t$-butyl fragment at the 4-position of central pyridyl unit of the 2,6-dipyrazolyl pyridine ancillary ( $c f$. Scheme 2). Moreover, the TF-2' is a modification of original TF-2, for which the 5-hexylthienyl group was judiciously substituted with dodecylthienyl group. This maneuver has effectively increased the solubility of sensitizers in dye solution, and afforded better processability and reproducibility in fabrication of solar cells. ${ }^{\mathbf{4 2 , 4 3}}$ As for the class of TF- $t \mathrm{Bu}$ sensitizers, the $t$-Bu substituent is known for its capability in suppressing intermolecular $\pi \pi$ stacking occurred between the planar chelate of sensitizers and preventing dye aggregation on the $\mathrm{TiO}_{2}$ surface, ${ }^{\mathbf{4 4 - 4 6}}$ both would afford better DSC efficiency $v s$. those without alkyl substituents. In contrast, TF-2 and TF-2' derivatives with the thien-2-yl fragment are notable for the enhanced optical response for the single

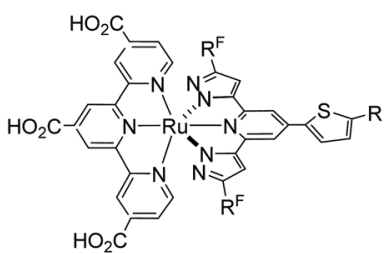

$T F-2, R=\mathrm{C}_{6} \mathrm{H}_{13}, \mathrm{R}^{\mathrm{F}}=\mathrm{CF}_{3}$

TF-2', R $=\mathrm{C}_{12} \mathrm{H}_{25}, \mathrm{R}^{\mathrm{F}}=\mathrm{CF}_{3}, \mathrm{C}_{3} \mathrm{~F}_{7}$

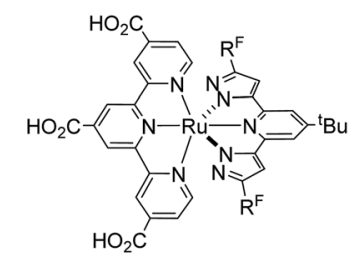

TF-tBu, $R^{F}=C_{3}, C_{3} F_{7}, C_{5} F_{11}, C_{7} F_{15}$

Scheme 2 Structural drawings of TF-2, TF- $2^{\prime}$ and TF-tBu series of $\mathrm{Ru}($ (I) sensitizers.

molecule due to the extended $\pi$-conjugation and enlarged absorption extinction coefficient. Hence, understanding of these properties should be of valuable in designing better DSC sensitizers as well as associated devices.

\section{Results and discussion}

\section{Synthesis and structural characterization}

The 2,6-dipyrazolyl pyridine ancillaries, i.e. with either 5-dodecylthien-2-yl or $t$-butyl fragment at the 4-position of central pyridyl unit and various perfluoroalkyl groups at the pyrazolyl sites were synthesized for fine-tuning the UV-Vis absorption, physical and photovoltaic properties (Scheme 3). Chelate L-2 was obtained using literature method, ${ }^{47,48}$ while chelates L-2_ $\mathrm{C}_{3} \mathrm{~F}_{7}$ was synthesized using pentyl perfluorobutyrate instead of ethyl perfluorobutyrate. The employment of pentyl ester is for increasing the miscibility in reaction media; otherwise, serious foaming will take place to reduce the product yield. Similarly, the $t$-Bu substituted chelates, i.e. $\mathrm{L}$ - $t \mathrm{Bu} \mathrm{R}^{\mathrm{F}}, \mathrm{R}^{\mathrm{F}}=\mathrm{CF}_{3}, \mathrm{C}_{3} \mathrm{~F}_{7}, \mathrm{C}_{5} \mathrm{~F}_{11}$ and $\mathrm{C}_{7} \mathrm{~F}_{15}$, were obtained from 2,6-diacetyl-4-t-butyl pyridine using identical protocol. After then, the sequential reaction of $\mathrm{RuCl}_{3} \cdot 3 \mathrm{H}_{2} \mathrm{O}$ with $4,4^{\prime}, 4^{\prime \prime}$-triethoxycarbonyl-2,2': $6^{\prime}, 2^{\prime \prime}$-terpyridine (tectpy), followed by treatment with 2,6-dipyrazolyl pyridine afforded the ethoxycarbonyl substituted Ru(II) intermediate complexes. After column chromatography on silica and recrystallization, they were hydrolysis in mixed acetone and $1 \mathrm{M} \mathrm{NaOH}_{(\mathrm{aq})}$ to afford the final $\mathrm{Ru}$ (II) sensitizers $T F-2{ }^{\prime} R^{\mathrm{F}}$ and $\mathrm{TF}-\mathrm{t} \mathrm{Bu} \_\mathrm{R}^{\mathrm{F}}$, by precipitation upon acidification to $\mathrm{pH}=3$.

\section{Photophysical behaviors}

The absorption and normalized emission spectra of these TF series of sensitizers were recorded in DMF at a concentration of $1 \times 10^{-5} \mathrm{M}$, which are depicted in Fig. 1 , while their numeric spectral and electrochemical data are summarized in Table 1. All TF sensitizers display a broadened absorption at the higher energy region around $\sim 325 \mathrm{~nm}$, attributed to the intra-ligand $\pi \pi^{*}$ transition. In addition, they showed two more, slightly lower energy absorptions in the regions 402-421 $\mathrm{nm}$ and 502$510 \mathrm{~nm}$ with sufficiently large extinction coefficient in the range of 1.2-2.0 $\times 10^{4} \mathrm{M}^{-1} \mathrm{~cm}^{-1}$, respectively; together with the lowest energy metal-to-ligand charge transfer (MLCT) absorption extended down to $\sim 710 \mathrm{~nm}$ and beyond. ${ }^{45}$ Without doubt,
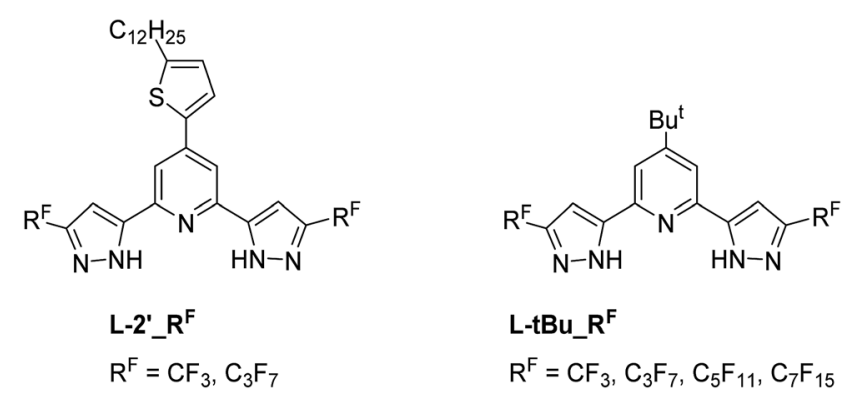

Scheme 3 Structural drawings of the studied 2,6-dipyrazolyl pyridine chelate. 


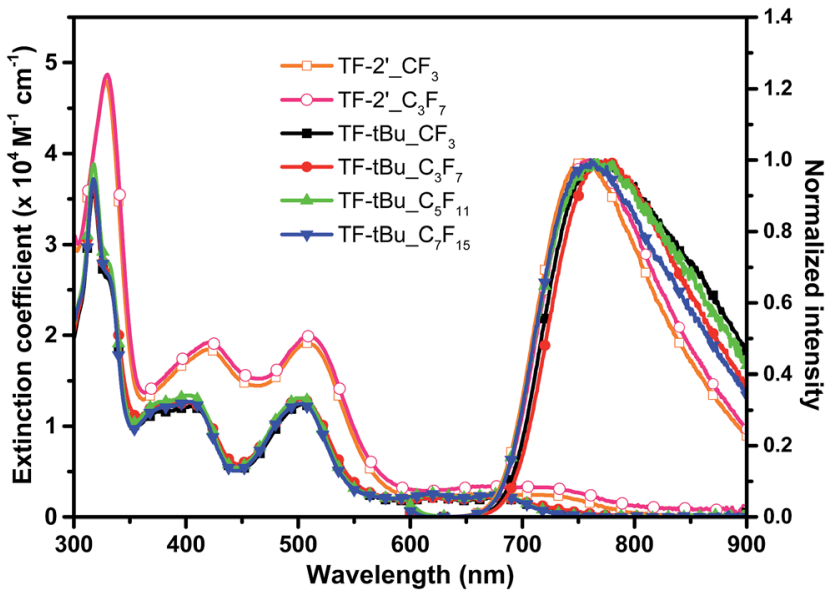

Fig. 1 UV-Vis absorption and normalized emission spectra of the studied TF sensitizers in DMF solution.

the much red-shifted peak position and the higher extinction coefficient for both sensitizers TF- $2^{\prime}{ }_{-} \mathrm{CF}_{3}$ and $\mathrm{TF}-2^{\prime}{ }_{-} \mathrm{C}_{3} \mathrm{~F}_{7}$ are due to the greater $\pi$-conjugation of thienyl appendage on the 2,6-dipyrazolyl pyridine ancillary.

\section{Electrochemical properties}

The ground and excited-state oxidation potentials ( $E_{\text {ox }}$ and $\left.E_{\text {red }}\right)$ of these TF sensitizers are next estimated using cyclic voltammetry and the spectroscopic measurement. As shown in Table 1, all of the ground-state oxidation potentials $0.93-0.95 \mathrm{~V}$ ( $v s$. normal hydrogen electrode, NHE) are more positive than that the $\mathrm{I}^{-} / \mathrm{I}_{3}{ }^{-}$redox couple ( $c a$. $0.35 \mathrm{~V} v$ s. NHE), despite of having various fluoroalkyl appendage attached at the ancillary chelate. This observation confirms the existence of sufficient electrochemical driving force for regeneration of oxidized sensitizers. Moreover, the excited-state oxidation potentials of -0.90 to $-0.93 \mathrm{~V}$, which were estimated from the difference of $E_{\text {red }}$ and the optical band gap, are also notably more negative than the conducting band potential (ca. $-0.5 \mathrm{~V} v s$. NHE) of nanocrystalline $\mathrm{TiO}_{2}$, confirming the occurrence of effective electron injection.

\section{Photovoltaic performances}

For the device fabrication, the anode consisted of a $15 \mu \mathrm{m}$ layer of $20 \mathrm{~nm}$ sized transparent $\mathrm{TiO}_{2}$ (anatase) nanoparticles and a second $5 \mu \mathrm{m}$ layer of $400 \mathrm{~nm}$ sized scattering particles, both were deposited by screen printing to form a square with dimensions of $0.50 \times 0.50 \mathrm{~cm}^{2}$. The $\mathrm{TiO}_{2}$ anode was immersed into either a $0.3 \mathrm{mM}$ solution of selected sensitizer in a mixture of DMSO and ethanol (v/v, 1:4) without co-adsorbent, or a solution of $0.3 \mathrm{mM}$ of sensitizer in mixed ethanol and $t$-butanol (v/v, 1:1), along with $0.6 \mathrm{mM}$ of tetrabutylammonium deoxycholate [TBA][DOC] as co-adsorbent, with an intention for boosting DSC efficiency. ${ }^{49}$ The employment of distinctive solvent mixture is intended for improving the solubility of co-adsorbent, while the typical dyeing process require approx. 18 hours to complete. Next, the counter electrodes were prepared from commercially available FTO glass (7 $\Omega /$ TEC7, $2.2 \mathrm{~mm}$ thick, Pilkington) and a solution of PVP capped platinum nanoclusters (PVP-Pt) via a so-called "two-step dip-coating" process, followed by a post thermal annealing at $325{ }^{\circ} \mathrm{C}$ for $10 \mathrm{~min}$. The cells were assembled using a hot-melt Surlyn film (Meltonix 1170-25, $25 \mathrm{~mm}$, Solaronix), and heated at $135{ }^{\circ} \mathrm{C}$. Electrolyte contains $0.6 \mathrm{M}$ 1,2-dimethyl-3propylimidazolium iodide (DMPII), $0.1 \mathrm{M}$ lithium iodide, $0.05 \mathrm{M}$ iodine, and $0.5 \mathrm{M} t$-butylpyridine $(t \mathrm{BP})$ in acetonitrile. This solution was injected into the assembled cell through a pre-drilled hole at the counter electrode.

Fig. 2(a) and (b) depicted the photocurrent-voltage response of the DSC devices fabricated using aforementioned dye solution, i.e. with and without the co-adsorbent [TBA][DOC]. The corresponding performances were recorded under AM $1.5 \mathrm{G}$ simulated sunlight at $100 \mathrm{~mW} \mathrm{~cm}{ }^{-2}$. The sensitizer TF-2' with co-adsorbent showed short-circuit current density $\left(J_{\mathrm{SC}}\right)$, opencircuit voltage $\left(V_{\mathrm{OC}}\right)$, fill factor $(\mathrm{FF})$, and overall conversion

Table 1 Absorbance and electrochemical properties of the studied Ru(॥) sensitizers

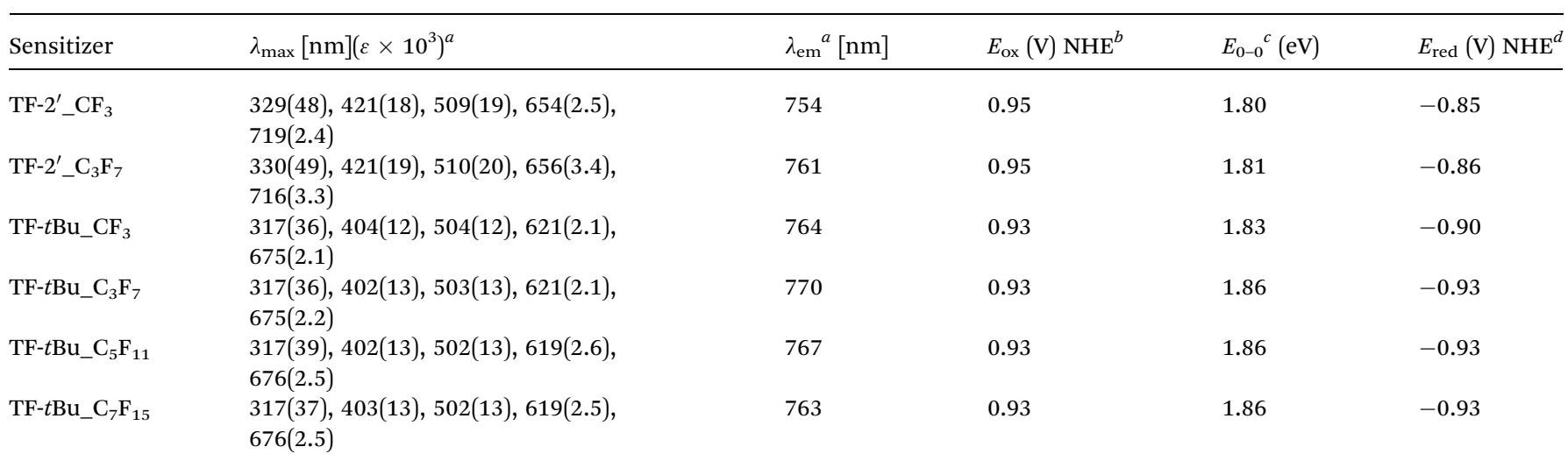

${ }^{a}$ Photophysical data were measured in DMF solution at $1 \times 10^{-5} \mathrm{~mol} \mathrm{~L}^{-1} \cdot{ }^{b} E_{\mathrm{Ox}}$ were measured in DMF with $0.1 \mathrm{M}\left({ }^{n} \mathrm{Bu}\right)_{4} \mathrm{NPF}_{6}$ as electrolyte. It was calibrated with $\mathrm{FcH} / \mathrm{FcH}^{+}$as internal reference and converted to $\mathrm{NHE}$ by addition of $0.63 \mathrm{~V} .{ }^{c} E_{0-0}$ was derived the intersection of the absorption and tangent of emission in DMF. ${ }^{d} E_{\mathrm{red}}$ was calculated according to equation $E_{\mathrm{ox}}-E_{0-0}$. 

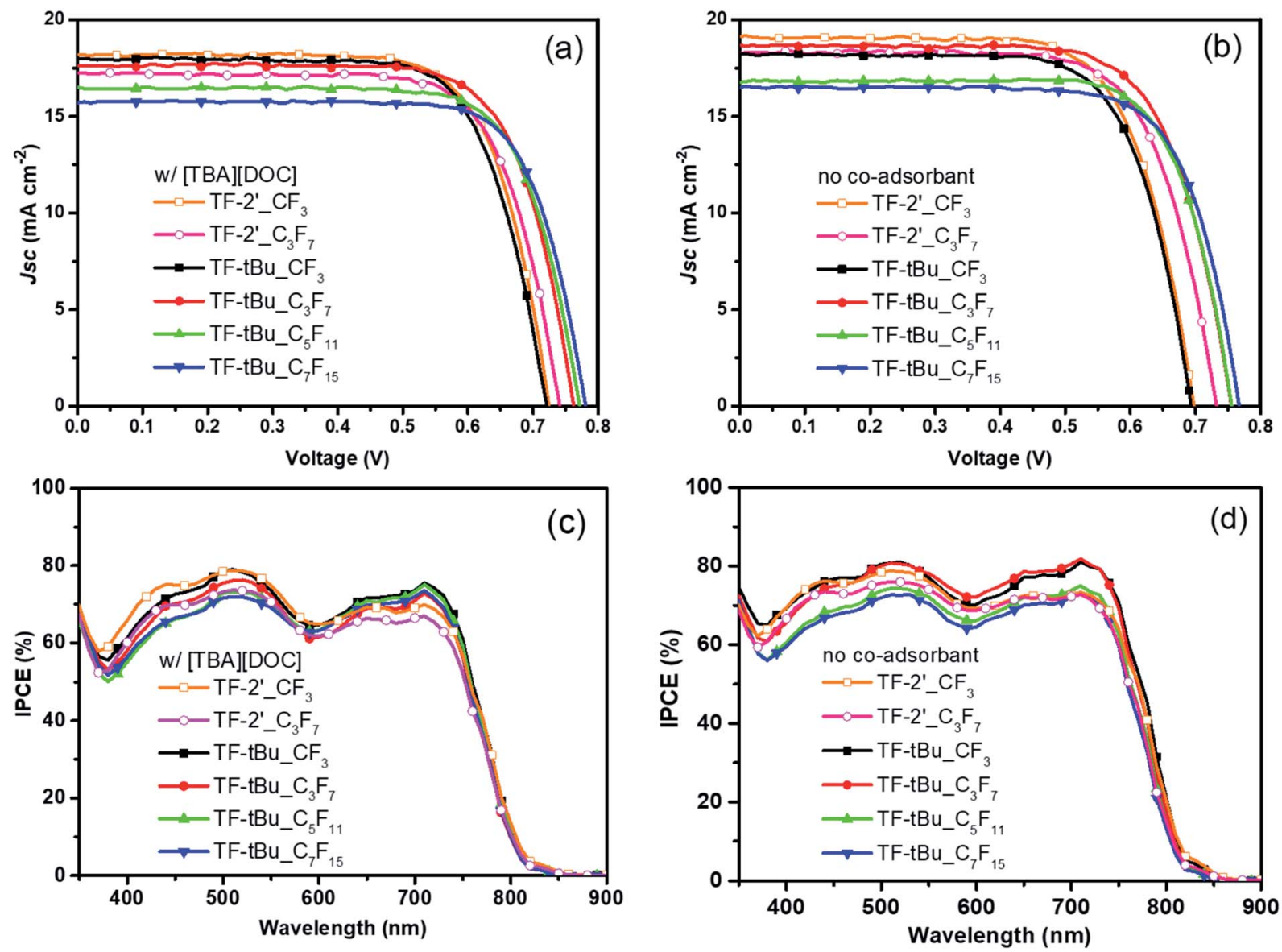

Fig. 2 J-V curve measured under AM 1.5 simulated sunlight for DSC cells with and without co-adsorbent (a) and (b), and the corresponding incident photon-to-electron conversion efficiency (IPCE) spectra (c) and (d).

efficiency (PCE) of $18.25 \mathrm{~mA} \mathrm{~cm}^{-2}, 723 \mathrm{mV}, 0.72$ and $9.53 \%$, while the respective TF-2 ${ }^{\prime}{ }_{-} \mathrm{C}_{3} \mathrm{~F}_{7}$ gave a slightly lowered performances, $c f$. $17.18 \mathrm{~mA} \mathrm{~cm}{ }^{-2}, 737 \mathrm{mV}, 0.73$ and 9.22\% ( $c f$. Table 2). The reduced efficiencies of TF- $2^{\prime}{ }_{-} \mathrm{C}_{3} \mathrm{~F}_{7}$ can be partly explained by the reduced dye loading shown in Table 2 . Remarkably, upon removal of the co-adsorbent, the overall efficiency of $\mathrm{TF}-2^{\prime}$ decreased slightly $(c f$. $\mathrm{PCE}=9.47 \% v s$. $9.53 \%)$, but the efficiency of $\mathrm{TF}-2^{\prime}{ }_{-} \mathrm{C}_{3} \mathrm{~F}_{7}$ showed marked

Table 2 The performances for DSC measured under AM $1.5 \mathrm{G}$ one sun irradiation ${ }^{a, b}$

\begin{tabular}{|c|c|c|c|c|c|c|}
\hline Sensitizer & Coads. & $V_{\mathrm{OC}}[\mathrm{mV}]$ & $J_{\mathrm{SC}}\left[\mathrm{mA} \mathrm{cm} \mathrm{cm}^{-2}\right]$ & $\mathrm{FF}$ & PCE [\%] & Dye loading $\left[\times 10^{-7} \mathrm{~mol} \mathrm{~cm}^{-2}\right]$ \\
\hline \multirow[t]{2}{*}{$\mathrm{TF}-2^{\prime} \_\mathrm{CF}_{3}$} & $\mathrm{Y}$ & $723(7)$ & $18.25(15)$ & $0.72(1)$ & $9.53(2)$ & 1.73 \\
\hline & $\mathrm{N}$ & $703(7)$ & $19.17(13)$ & $0.70(1)$ & $9.47(5)$ & 1.82 \\
\hline & $\mathrm{N}$ & $727(3)$ & $18.57(6)$ & $0.71(1)$ & $9.61(3)$ & 1.71 \\
\hline \multirow[t]{2}{*}{ TF- $t$ Bu_CF ${ }_{3}$} & $\mathrm{Y}$ & $723(7)$ & $17.99(32)$ & $0.72(1)$ & $9.35(6)$ & 1.95 \\
\hline & $\mathrm{N}$ & $686(4)$ & $18.35(16)$ & $0.72(1)$ & $9.05(6)$ & 2.20 \\
\hline \multirow[t]{2}{*}{ TF- $t$ Bu_C $\mathrm{C}_{5} \mathrm{~F}_{11}$} & $\mathrm{Y}$ & $767(3)$ & $16.47(1)$ & $0.74(1)$ & $9.39(6)$ & 1.58 \\
\hline & $\mathrm{N}$ & $763(7)$ & $16.50(26)$ & $0.74(1)$ & $9.39(10)$ & 1.60 \\
\hline \multirow[t]{2}{*}{ TF- $t$ Bu_ $C_{7} F_{15}$} & $\mathrm{Y}$ & $773(7)$ & $15.72(8)$ & $0.75(1)$ & $9.25(5)$ & 1.42 \\
\hline & $\mathrm{N}$ & $767(3)$ & $16.63(12)$ & $0.72(1)$ & $9.31(4)$ & 1.55 \\
\hline
\end{tabular}

${ }^{a}$ The devices were fabricated using $15+5 \mu \mathrm{m}$ of $\mathrm{TiO}_{2}$ layer with an activated surface area of $5 \times 5 \mathrm{~mm}^{2}$. Device performances were measured using a black metal mask with an aperture area of $4 \times 4 \mathrm{~mm}^{2}$. The loading is calculated from the absorption intensity of desorbed dye solution versus a reference solution with $0.01 \mathrm{mM}$ of dye and $0.1 \mathrm{M}$ of [TBA]OH in a $1: 1(\mathrm{v} / \mathrm{v})$ mixture of $\mathrm{MeOH}$ and water. ${ }^{b} \mathrm{Y}$ and $\mathrm{N}$ stand for cells that were fabricated with and without the addition of $0.6 \mathrm{mM}$ of [TBA][DOC] co-adsorbent, respectively. 
increase from $\mathrm{PCE}=9.22 \%$ to $9.61 \%$, consistent with the fact that the $\mathrm{C}_{3} \mathrm{~F}_{7}$ group has effectively reduced both the dye aggregation and charge recombination even in absence of coadsorbent, due to the larger hydrophobic behavior of $\mathrm{C}_{3} \mathrm{~F}_{7}$ substituent.

Furthermore, upon replacement of dodecylthien-2-yl on 2,6dipyrazolyl pyridine ancillary with $t$-butyl substituent, giving the TF- $t$ Bu series of sensitizers. The parent TF- $t$ Bu showed lowered preferences $v s$. those of previously discussed TF-2', despite of having a notable increase in dye loading for both cells fabricated with and without the co-adsorbent in dye solution. Such a poor efficiency could be related to the inferior $V_{\mathrm{OC}}$ and $J_{\mathrm{SC}}$ obtained $v s$. TF-2' . Remarkably, upon changing $\mathrm{R}^{\mathrm{F}}$ substituents, the corresponding TF- $t \mathrm{Bu} \mathrm{C}_{3} \mathrm{~F}_{7}$ devices give good performance (i.e. $\mathrm{PCE}=9.78 \%$ and $10.05 \%$ ) in presence or absence of coadsorbent, despite of having relatively reduced dye loadings under both condition. This set of data turned out to be the best ever obtained among all TF- $t \mathrm{Bu}$ based sensitizers, as upon further change of sensitizers to TF- $t \mathrm{Bu}_{-} \mathrm{C}_{5} \mathrm{~F}_{11}$ and $\mathrm{C}_{7} \mathrm{~F}_{15}$, i.e. increasing the length of perfluoroalkyl groups, the devices gave steadily reduced device characteristics, even they have showed the much improved $V_{\text {OC }} v s$. all sensitizers studied.

The incident photon-to-current conversion efficiencies (IPCEs) of these DSC devices are shown in Fig. 2(c) and (d). The onsets of the IPCE spectra are all close to $830 \mathrm{~nm}$, and with excellent IPCE performances in region from $450 \mathrm{~nm}$ to $720 \mathrm{~nm}$. In absence of co-adsorbent [TBA][DOC], the sensitizers TF- $t \mathrm{Bu}$ $\left(\mathrm{R}^{\mathrm{F}}=\mathrm{CF}_{3}, \mathrm{C}_{3} \mathrm{~F}_{7}\right)$ exhibit two maximum IPCE of over $80 \%$ at $\sim 510 \mathrm{~nm}$ and $720 \mathrm{~nm}$ respectively, while all other sensitizers showed slightly inferior IPCEs. This observation could be understood in terms of the combined effect of better light harvesting caused by the increased dye loading and reduced charge recombination. Furthermore, the TF-2' sensitizers with $\mathrm{R}^{\mathrm{F}}=\mathrm{CF}_{3}$ and $\mathrm{C}_{3} \mathrm{~F}_{7}$ were no longer exhibited higher IPCE at the longer wavelength region between $600 \mathrm{~nm}$ and $800 \mathrm{~nm}$, despite of having higher molar extinction coefficient in their UV-Vis absorption spectra, attributed to the thienyl substituent.

\section{Physical insights}

To further probe the device performances, the charge extraction (CE) and intensity-modulated photovoltage spectroscopy (IMVS) were measured and the corresponding data are shown in Fig. 3(a)-(d). The differences in the $V_{\text {OC }}$ between the cells can generally be explained by shifts in the $\mathrm{TiO}_{2}$ conduction band edge $^{50,51}$ and differences in electron lifetimes in response to the electron recombination reaction. ${ }^{52-54}$
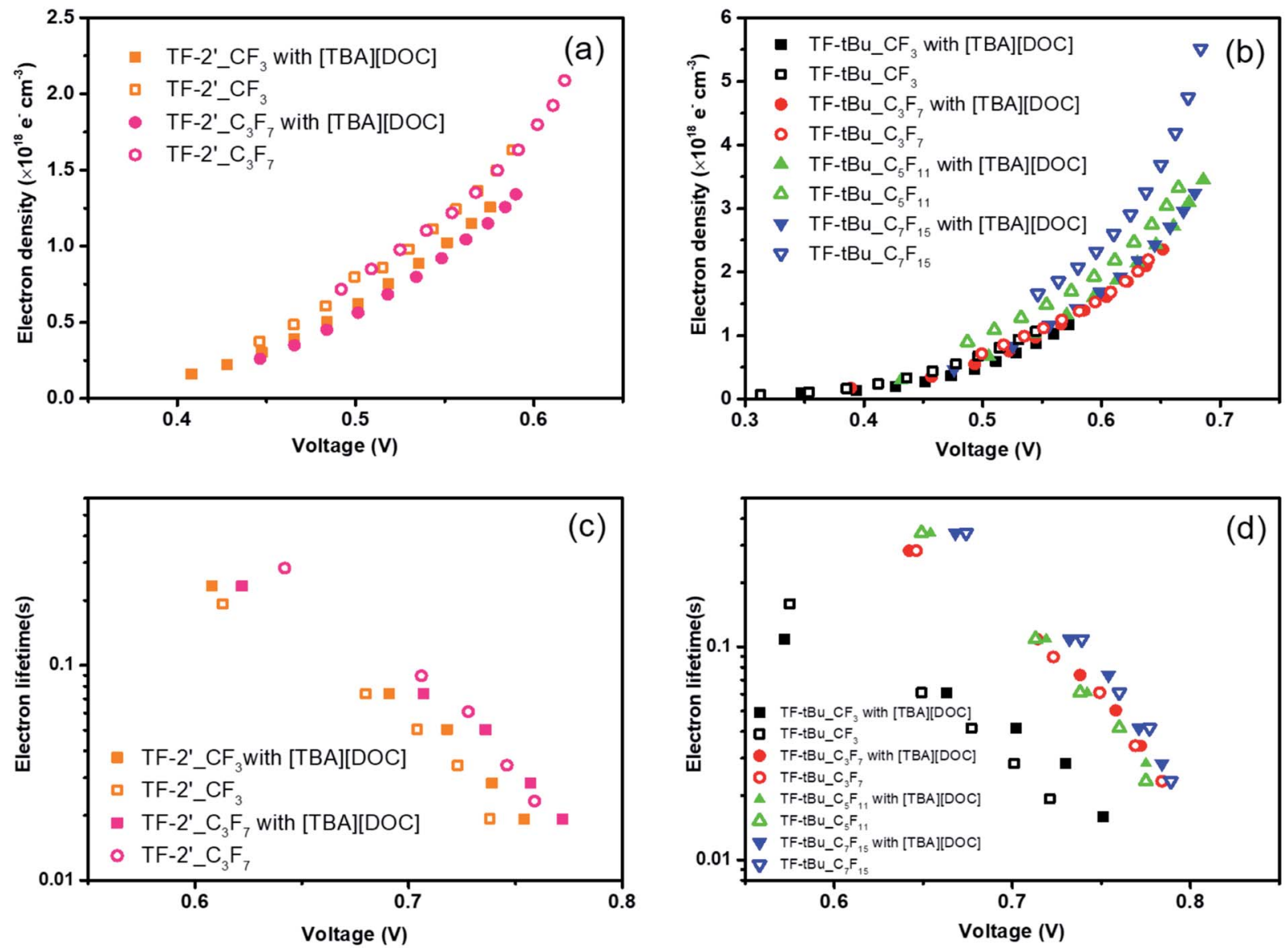

Fig. $3 \mathrm{TiO}_{2}$ electron density versus voltage deduced from charge extraction measurements of the studied sensitizers (a) and (b), and electron lifetime versus $\mathrm{TiO}_{2}$ electron density deduced from transient photovoltage measurements for respective DSC devices (c) and (d). The cell voltage is controlled via tuning the illumination from a halogen lamp. 
Fig. 3(a) and (b) showed the extracted charge density at various recorded $V_{\mathrm{OC}}$ 's for DSC devices fabricated using studied sensitizers. It is worth noting that $V_{\mathrm{OC}}$ decays are dependent on the accumulated charge in the $\mathrm{TiO}_{2}$ conduction band, and so to obtain a fair comparison of the recombination dynamics between different sensitizers, their charge density must be equal. It appears that similar electron densities were obtained for both TF-2' sensitizers, independent to the $\mathrm{CF}_{3}$ and $\mathrm{C}_{3} \mathrm{~F}_{7}$ substituents. On the other hand, addition of co-adsorbent yielded an increased $V_{\mathrm{OC}}$, which can be explained by a negative surface charge buildup that caused the band edges to shift upward, giving a higher photovoltage. As for the TF- $t$ Bu series of sensitizers, all cells fabricated with co-adsorbent showed relatively higher $V_{\mathrm{OC}}$ compared with those without co-adsorbent. Moreover, cells fabricated with TF- $t \mathrm{Bu}_{-} \mathrm{C}_{5} \mathrm{~F}_{11}$ and TF$t \mathrm{Bu}_{-} \mathrm{C}_{7} \mathrm{~F}_{15}$ in absence of co-adsorbent showed the lowest and the second lowest $V_{\mathrm{OC}}$, while TF- $t \mathrm{Bu} \mathrm{CF}_{3}$ and $\mathrm{TF}-t \mathrm{Bu} \mathrm{C}_{3} \mathrm{~F}_{7}$ regained their high $V_{\mathrm{OC}}$ in absence of co-adsorbent, showing the advantage of shortened fluoroalkyl groups, i.e. $\mathrm{CF}_{3}$ and $\mathrm{C}_{3} \mathrm{~F}_{7}$.

Fig. 3(c) and (d) showed the plot of electron lifetime versus $V_{\mathrm{OC}}$ of the studied devices, as obtained from the IMVS experiments. In general, all TF-2 ${ }^{\prime}$ and $\mathrm{TF}-t \mathrm{Bu}$ sensitizers with the longer perfluoroalkyl substituents showed longer lifetime at any given $V_{\mathrm{OC}}$. Particularly, in the TF- $t \mathrm{Bu}$ series of sensitizers, the TF- $t \mathrm{Bu} \mathrm{CF}_{3}$ showed the shortest lifetime and fastest recombination, while those with $\mathrm{C}_{3} \mathrm{~F}_{7}$ and higher fluoroalkyl group (i.e. $\mathrm{C}_{5} \mathrm{~F}_{11}$ and $\mathrm{C}_{7} \mathrm{~F}_{15}$ ) exhibited comparable long electron lifetime, an observation that is attributed to the gradually reduced influence on variation of chain length. Overall, the combined CE and IMVS results indicated that devices constructed with those bearing longer perfluoroalkyl chain show more stabilized conduction band edge in absence of co-adsorbent, and longer lifetimes due to the suppressed back-electron transfer (i.e. charge recombination).

To clarify the governing factors on the photovoltaic performances of DSC devices, electrochemical impedance spectroscopy was also utilized to analyze the resistance to charge recombination in these devices. Nyquist plots were measured in the dark with varied forward bias. The data obtained during an electrochemical impedance measurement is usually conducted by fitting the experimental results with an equivalent circuit. ${ }^{55,56}$ Fig. 4 showed the trend of charge transfer resistance $\left(R_{\mathrm{CT}}\right)$ at the interface of $\mathrm{TiO}_{2} /$ dye/electrolyte, ${ }^{57}$ among which Fig. 4(a) demonstrated the electrochemical impedance illustration of both $\mathrm{TF}^{\prime}{ }^{\prime}{ }_{-} \mathrm{CF}_{3}$ and TF- $2^{\prime}{ }_{-} \mathrm{C}_{3} \mathrm{~F}_{7}$, and in presence and absence of [TBA][DOC], for which all studies showed highly similar $R_{\mathrm{CT}}$ at the same applied bias, as well as the slightly larger $R_{\mathrm{CT}}$ for the sensitizer TF- $2^{\prime}{ }_{-} \mathrm{C}_{3} \mathrm{~F}_{7}$. Similarly, as depicted in Fig. $4(\mathrm{~b})$, the TF- $t$ Bu series of sensitizers showed similar $R_{\mathrm{CT}}$, which was independent to the co-adsorbent [TBA][DOC]. In addition, the $R_{\mathrm{CT}}$ is increased with the length of perfluoroalkyl substituents. The highest resistance is obtained for the TF- $t \mathrm{Bu}_{-} \mathrm{C}_{7} \mathrm{~F}_{15}$ devices, confirming the trend obtained for the TF- $2^{\prime}$ derivatives; i.e. longer chain length would prevent the electron recombination at the $\mathrm{TiO}_{2} /$ dye/electrolyte interface.

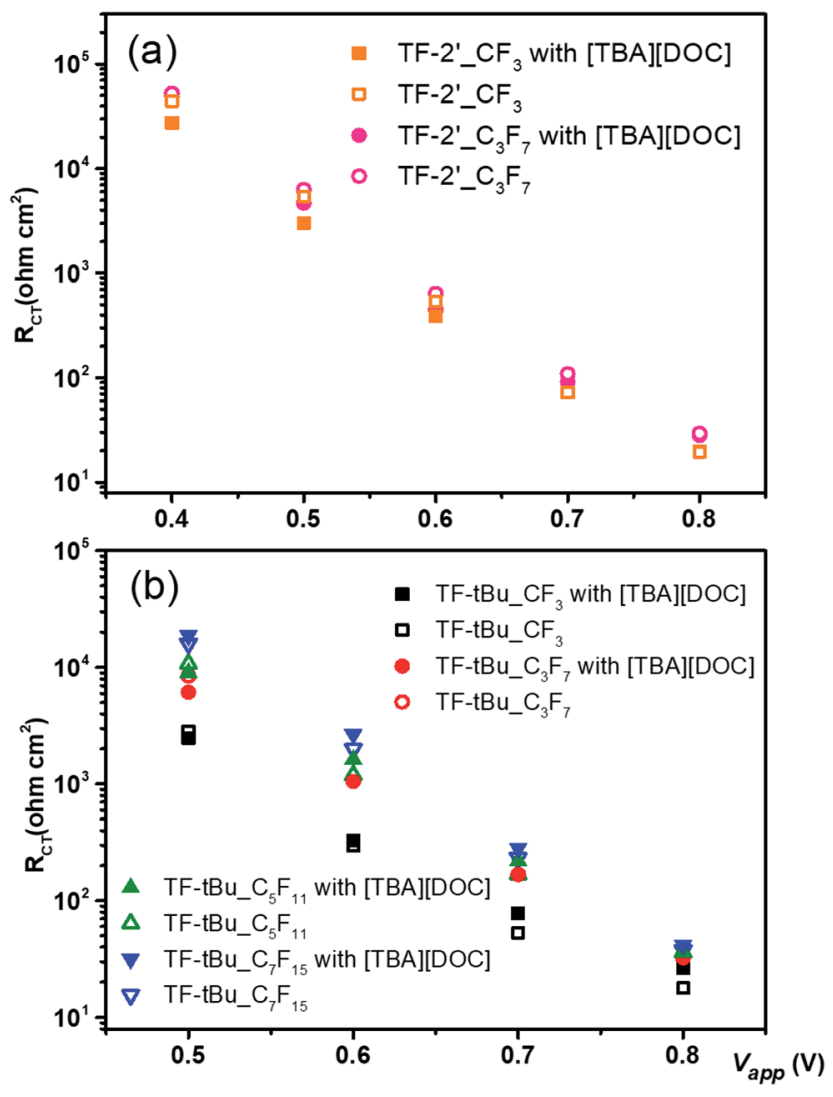

Fig. 4 Electrochemical impedance spectra of DSC devices tested in dark with an external bias as each corresponding $V_{\text {OC }}$ under one-sun illumination.

\section{Sensitizer wettability}

Modification of interfacial contact induced by changing the perfluoroalkyl substituents can be studied by contact angle measurements. ${ }^{58}$ Generally speaking, contact angles of $>90^{\circ}$ indicate relatively hydrophobic character, while values of $<90^{\circ}$ denote the hydrophilic surface under examination. ${ }^{59,60}$ Fig. 5 shows the illustration of contact angles (CA) upon application of $0.05 \mathrm{~mL}$ of water droplet at the sensitized $\mathrm{TiO}_{2}$ film. It appears that the parent sensitizers $\mathrm{TF}-2^{\prime}$ and $\mathrm{TF}-t \mathrm{Bu}_{-} \mathrm{CF}_{3}$ produce similar contact angles of $14.03^{\circ}$ and $13.81^{\circ}$, showing the reduced hydrophobic character. Then, the sensitizers modified with $\mathrm{C}_{3} \mathrm{~F}_{7}$ fragments became more hydrophobic by showing $\mathrm{CA}$ of $30.14^{\circ}$ and $60.78^{\circ}$ for TF- $2^{\prime}{ }_{-} \mathrm{C}_{3} \mathrm{~F}_{7}$ and TF- $t \mathrm{Bu}_{-} \mathrm{C}_{3} \mathrm{~F}_{7}$, respectively. Finally, the sensitizers TF- $t$ Bu_ $\mathrm{C}_{5} \mathrm{~F}_{11}$ and TF- $t$ Bu_ $\mathrm{C}_{7} \mathrm{~F}_{15}$ exhibited the much greater $\mathrm{CA}$ value of $76.82^{\circ}$ and $122.20^{\circ}$. This result is consistent with the findings in IMVS, for which the longer perfluoroalkyl chain would prevent the electron recombination at the $\mathrm{TiO}_{2}$ interface.

\section{Device stability}

To test the long-term stability, two representative solar cells were fabricated using TF- $t \mathrm{Bu}_{-} \mathrm{CF}_{3}$ and TF- $t \mathrm{Bu}_{-} \mathrm{C}_{3} \mathrm{~F}_{7}$, together with a low-volatility electrolyte composed of $1 \mathrm{M}$ DMPII, $0.15 \mathrm{M}$ $\mathrm{I}_{2}, 0.2 \mathrm{M} \mathrm{NaI}, 0.1 \mathrm{M}$ GuNCS, and $0.5 \mathrm{M}$ NBB ( $N$-butyl- $1 H^{-}$ 
TF-2'_CF 3

Contact angle: 14.03

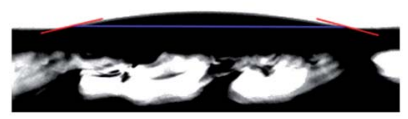

TF-tBu_CF 3 Contact angle: 13.81

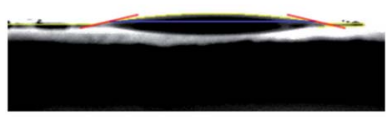

TF-tBu_C $\mathrm{F}_{5} \mathrm{~F}_{11}$

Contact angle: 76.02

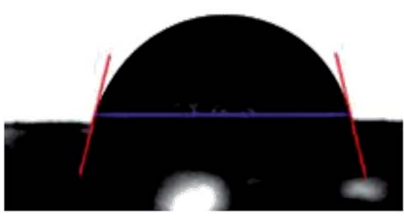

Fig. 5 Contact angles of the sensitizers with different perfluoroalkyl side chain at the surface of dye-coated $\mathrm{TiO}_{2}$ films.

benzimidazole) in 3-methoxypropionitrile (MPN). ${ }^{61}$ Both cells were subjected to the accelerated light soaking test at $65{ }^{\circ} \mathrm{C}$ for $1500 \mathrm{~h}$. Their performances are summarized in Fig. 6. As can be seen, both TF- $t \mathrm{Bu} \mathrm{CF}_{3}$ and TF- $t \mathrm{Bu} \mathrm{C}_{3} \mathrm{~F}_{7}$-based cells showed consistently higher performances in $J_{\mathrm{SC}}, V_{\mathrm{OC}}$, and FF. Of particular interest are the final $\operatorname{PCE}(\eta)$ and the decay in efficiency $(\Delta)$, which is defined as $\left(\eta_{\max }-\eta_{1500 \mathrm{~h}}\right) / \eta_{\max }$. They were calculated to be PCE $=8.33 \%, \Delta=8.36 \%$ for TF- $t \mathrm{Bu}_{-} \mathrm{C}_{3} \mathrm{~F}_{7}$, and
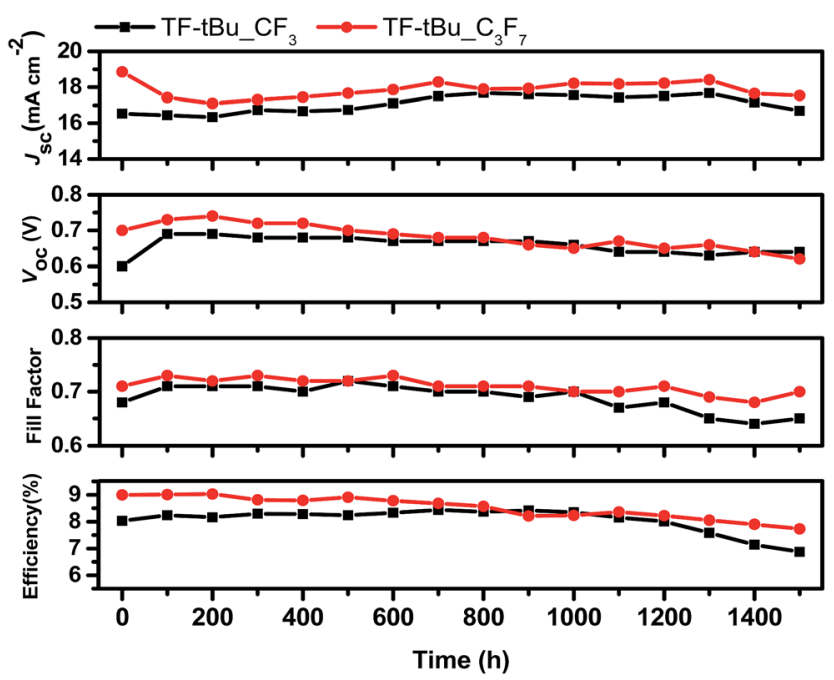

Fig. 6 Device performances of all studied DSC under one-sun light soaking at $65^{\circ} \mathrm{C}$ for $1500 \mathrm{~h}$. Electrolyte is composed of $1 \mathrm{M} \mathrm{DMII}$, $0.15 \mathrm{M} \mathrm{I}_{2}, 0.2 \mathrm{M} \mathrm{Nal}, 0.1 \mathrm{M}$ GuNCS, and $0.5 \mathrm{M}$ NBB in 3-methoxypropionitrile.
PCE $=7.0 \%, \Delta=21.6 \%$ for TF- $t \mathrm{Bu}_{-} \mathrm{CF}_{3}$. The excellent stability of TF- $t \mathrm{Bu} \mathrm{C}_{3} \mathrm{~F}_{7}$ over that of TF- $t \mathrm{Bu} \mathrm{CF}_{3}$ indicates its potential advantage for fabrication of the solar modules with adequate stability.

\section{Larger sized devices}

Large sized solar cell module using TF- $t$ Bu_ $\mathrm{C}_{3} \mathrm{~F}_{7}$ sensitizer was also fabricated in an attempt to verify their potential usage in actual application. ${ }^{62}$ As shown in Fig. 7, the fabricated DSC module consists of two parallel $\mathrm{TiO}_{2}$ strips, each coated with a $15 \mu \mathrm{m}$ of the dye-absorbing layer $(20 \mathrm{~nm})$ plus a larger diameter light scattering layer $(5 \mu \mathrm{m}, 400 \mathrm{~nm})$, giving a total active area of $0.98 \times 5.7 \times 2 \mathrm{~cm}^{2}\left(\right.$ e.g. $\left.11.2 \mathrm{~cm}^{2}\right)$. The cell was fabricated using the previously mentioned protocol, except that a grid of silver wires was printed on both $\mathrm{TiO}_{2}$ anode and Pt-based counter electrode using commercial silver paste to improve the collection of photocurrent. The silver wires were next covered by glass paste to protect against the possible corrosion and unwanted contact with the electrolyte. After then, the cell was carefully assembled using Surlyn to ensure good insulation around the silver grids. The performances are listed in Table 3, showing a $J_{\mathrm{SC}}$ of $18.51 \mathrm{~mA}$ $\mathrm{cm}^{-2}$, a $V_{\text {OC }}$ of $737 \mathrm{mV}$, a FF of 0.55 and PCE of $7.55 \%$ under the standard AM 1.5 G solar irradiation. As can be seen, the $J_{\text {SC }}$ and $V_{\text {OC }}$ are comparable to those of the smaller area DSC devices, while the large reduction in FF is due to the inefficient collection of photocurrent and the increased diffusion resistance.

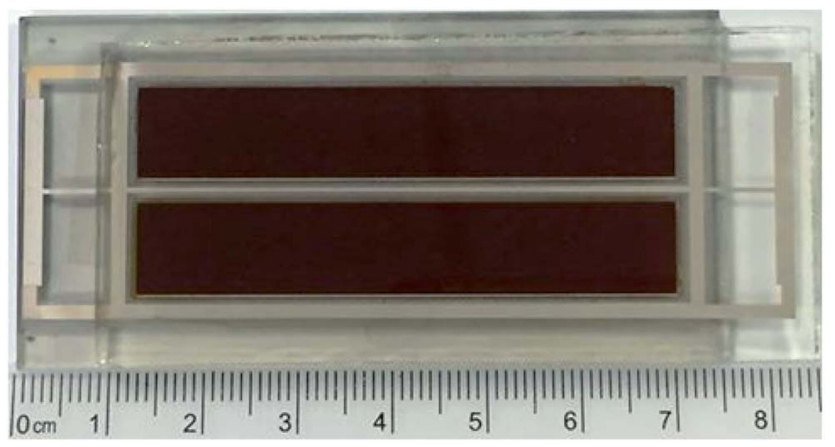

Fig. 7 Photograph of a larger sized DSC module.

Table 3 The performances for larger sized DSC module measured under AM 1.5 G one sun irradiation ${ }^{a}$

\begin{tabular}{llllll}
\hline Sensitizer & Coads. $^{b}$ & $V_{\mathrm{OC}}[\mathrm{mV}]$ & $J_{\mathrm{SC}}\left[\mathrm{mA} \mathrm{cm}^{-2}\right]$ & FF & PCE [\%] \\
\hline TF- $t$ Bu_C ${ }_{3} \mathrm{~F}_{7}$ & $\mathrm{Y}$ & $747(3)$ & $15.57(15)$ & $0.61(1)$ & $7.11(6)$ \\
& $\mathrm{N}$ & $737(3)$ & $18.51(4)$ & $0.55(1)$ & $7.55(7)$
\end{tabular}

${ }^{a}$ The devices were fabricated using a $15+5 \mu \mathrm{m}$ of $\mathrm{TiO}_{2}$ layer with an active area of $0.98 \times 5.7 \times 2 \mathrm{~cm}^{2}\left(\right.$ e.g. $\left.11.2 \mathrm{~cm}^{2}\right) .{ }^{b} \mathrm{Y}$ and $\mathrm{N}$ stand for the cells fabricated with and without the addition of co-adsorbent during dyeing. 


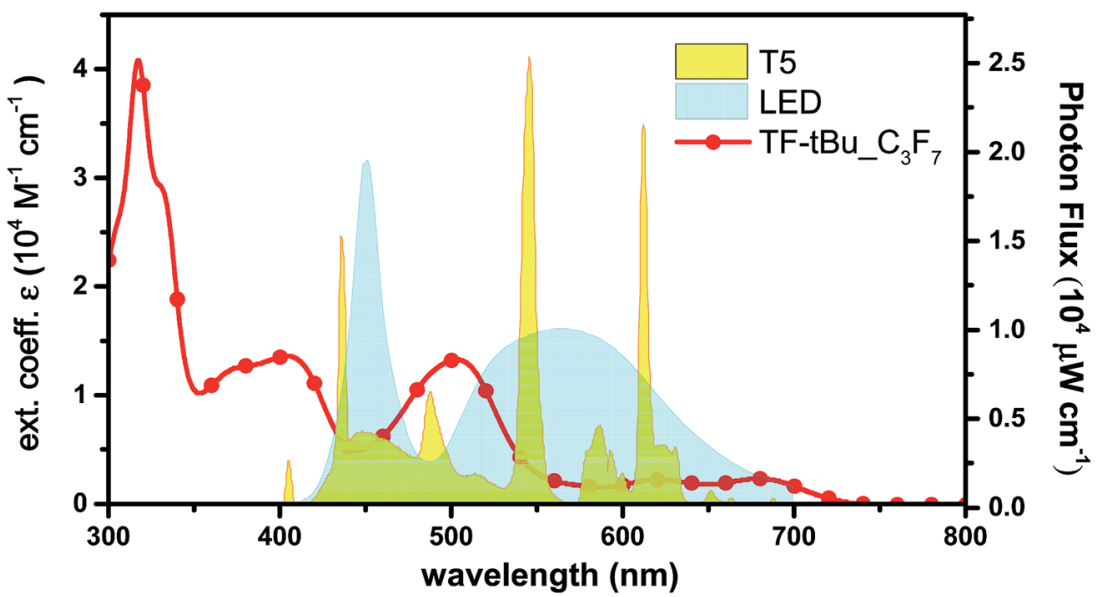

Fig. 8 Absorption of TF- $t B u_{-} C_{3} F_{7}$ vs. the spectral profile of T5 and LED lamp.

\section{Performance under indoor lighting}

DSCs are known to exhibit better performance $v s$. thin film silicon solar cells under ambient lighting, which open up the possibility to use DSCs as the constant power sources with reduced electric output in an indoor environment. ${ }^{63}$ In this study, we employed TF- $t$ Bu_ $\mathrm{C}_{3} \mathrm{~F}_{7}$ which is structurally simple, no need to add the co-adsorbent in dye solution and good power conversion efficiency in this series. It serves a candidate for measurement of DSC performance under indoor lighting. In Fig. 8, we compared the absorption spectrum of TF- $t$ Bu_ $\mathrm{C}_{3} \mathrm{~F}_{7}$ in the solution, together with emission spectral profiles of commercially available, T5 fluorescent tube and LED lamp.

Photovoltaic characters of the normal cell fabricated using $\mathrm{TF}-\mathrm{B} \mathrm{Bu}_{-} \mathrm{C}_{3} \mathrm{~F}_{7}$ and with dimension of $0.25 \mathrm{~cm}^{2}$ under various light intensities between 600 and 2400 lux are depicted in Table 4. Under illumination of standard T5 lamp, the device exhibits a $J_{\mathrm{SC}}$ of $0.08 \mathrm{~mA} \mathrm{~cm}^{-2}$ (at $600 \mathrm{lux}$ ) to $0.32 \mathrm{~mA} \mathrm{~cm}^{-2}$ (at $2400 \mathrm{lux}$ ) and a $V_{\text {OC }}$ of $540 \mathrm{mV}$ (600 lux) to $600 \mathrm{mV}$ (2400 lux), whereas under normal LED illumination, the cell provides a $J_{\mathrm{SC}}$ of $0.07 \mathrm{~mA} \mathrm{~cm}^{-2}$ (600 lux) to $0.27 \mathrm{~mA} \mathrm{~cm}^{-2}$ (2400 lux) and a $V_{\mathrm{OC}}$ of $520 \mathrm{mV}$ (600 lux) to $590 \mathrm{mV}$ (2400 lux). The employed light intensities $(600,1200$ and 2400 lux $)$ were based on the standard indoor illumination between 200 and 2000 lux. ${ }^{63}$ The slightly better performance recorded at higher luminance is attributed to an increased light intensity that reduced the influence of the variation of dark current. Overall, the cell generates an electric power efficiency of $0.69 \mathrm{~mW} \mathrm{~cm}^{-2}(\mathrm{PCE}=20.4 \%)$ and $0.73 \mathrm{~mW}$ $\mathrm{cm}^{-2}(\mathrm{PCE}=16.1 \%)$ under the illumination of T5 lamp and

Table 4 Photovoltaic properties of TF-tBu_C $\mathrm{C}_{3} \mathrm{~F}_{7}$ based DSC under different indoor illumination ${ }^{a}$

\begin{tabular}{|c|c|c|c|c|c|c|}
\hline Source & Lux & Light intensity $\left(\mathrm{mW} \mathrm{cm}^{-2}\right)$ & $V_{\mathrm{OC}}[\mathrm{mV}]$ & $J_{\mathrm{SC}}\left[\mathrm{mA} \mathrm{cm}^{-2}\right]$ & $\mathrm{FF}$ & PCE [\%] \\
\hline \multirow[t]{2}{*}{$\mathrm{T} 5$} & 600 & 0.176 & $540(3)$ & $0.08(13)$ & $0.73(1)$ & $16.68(3)$ \\
\hline & 1200 & 0.344 & $570(7)$ & $0.16(14)$ & $0.73(1)$ & $19.14(6)$ \\
\hline \multirow[t]{3}{*}{ LED } & 600 & 0.184 & $520(5)$ & $0.07(13)$ & $0.67(1)$ & $13.84(4)$ \\
\hline & 1200 & 0.367 & $560(3)$ & $0.14(17)$ & $0.73(1)$ & $15.48(5)$ \\
\hline & 2400 & 0.730 & $590(5)$ & $0.27(15)$ & $0.73(1)$ & $16.05(3)$ \\
\hline
\end{tabular}

${ }^{a}$ The cell consists of a dimension of $0.5 \times 0.5 \mathrm{~cm}^{2}$.

Table 5 The performances for larger sized DSC module under various indoor illumination ${ }^{a}$

\begin{tabular}{|c|c|c|c|c|c|c|}
\hline Source & Lux & Light intensity $\left(\mathrm{mW} \mathrm{cm}^{-2}\right)$ & $V_{\mathrm{OC}}[\mathrm{mV}]$ & $J_{\mathrm{SC}}\left[\mathrm{mA} \mathrm{cm}^{-2}\right]$ & $\mathrm{FF}$ & PCE $[\%]$ \\
\hline \multirow[t]{2}{*}{$\mathrm{T} 5$} & 600 & 0.176 & $460(5)$ & $0.06(30)$ & $0.68(1)$ & $10.05(8)$ \\
\hline & 1200 & 0.342 & $490(7)$ & $0.12(10)$ & $0.70(1)$ & $11.82(4)$ \\
\hline \multirow[t]{3}{*}{ LED } & 600 & 0.183 & $450(7)$ & $0.05(18)$ & $0.67(1)$ & $8.07(10)$ \\
\hline & 1200 & 0.363 & $480(5)$ & $0.10(12)$ & $0.70(1)$ & $9.37(3)$ \\
\hline & 2400 & 0.725 & $510(5)$ & $0.20(15)$ & $0.74(1)$ & $10.51(9)$ \\
\hline
\end{tabular}

${ }^{a}$ The devices were fabricated using a $15+5 \mu \mathrm{m}$ of $\mathrm{TiO}_{2}$ layer with an active area of $0.98 \times 5.7 \times 2 \mathrm{~cm}^{2}\left(\right.$ e.g. $\left.11.2 \mathrm{~cm}^{2}\right)$. 
LED, respectively. Then, we switched to the large sized module with area and measured their corresponding performances under the indoor lighting, for which the data are listed in Table 5. In general, the device gave slightly better performances under T5 vs. LED illumination, for which the best performances were $J_{\mathrm{SC}}$ of $0.24 \mathrm{~mA} \mathrm{~cm} \mathrm{~cm}^{-2}, V_{\mathrm{OC}}$ of $0.52 \mathrm{mV}$, FF of 0.72 and PCE of $12.7 \%$ at 2400 lux. Therefore, these optimal efficiencies under indoor confirms the better opportunity for DSC in harvesting ambient light energy $v s$. that for terrestrial power generation. ${ }^{63-65}$

\section{Conclusion}

A total of six distinctive, $4,4^{\prime}, 4^{\prime \prime}$-tricarboxy-2,2' $: 6^{\prime}, 2^{\prime \prime}$-terpyridine based Ru(II) sensitizers, i.e. TF-2 ${ }^{\prime}{ }_{-} \mathrm{C}_{n} \mathrm{~F}_{2 n+1}(n=1$ and 3$)$ and TF$t$ Bu_ $\mathrm{C}_{n} \mathrm{~F}_{2 n+1}(n=1,3,5$ and 7$)$ with either 5-dodecylthien-2-yl $\left(\mathrm{TF}-2^{\prime}\right)$ or $t$-butyl substituent (TF- $\left.t \mathrm{Bu}\right)$ at the central pyridyl unit and four distinctive perfluoroalkyl fragments (e.g. $\mathrm{CF}_{3}$, $\mathrm{C}_{3} \mathrm{~F}_{7}, \mathrm{C}_{5} \mathrm{~F}_{11}$ and $\mathrm{C}_{7} \mathrm{~F}_{15}$ ) at both terminal pyrazolyl sites of the 2,6dipyrazolyl pyridine ancillary are synthesized and tested for DSC performances. Disregarding to the higher extinction coefficient of the 5-dodecylthien-2-yl substituted sensitizers versus the $t$-butyl substituted analogues, the latter showed the best overall PCE of $10.05 \%$ for TF- $t$ Bu_ $\mathrm{C}_{3} \mathrm{~F}_{7}$ vs. those of corresponding TF$2^{\prime}{ }_{-} \mathrm{C}_{3} \mathrm{~F}_{7}(9.61 \%)$, which are attributed to the increased loading on the sensitized $\mathrm{TiO}_{2}$ surface. Particularly, the introduction of $\mathrm{C}_{3} \mathrm{~F}_{7}$ substituent also eliminate the necessity of using coadsorbent, which is beneficial for increasing the lifespan of DSC under the practical operating condition. Moreover, due to an ample supply of $\mathrm{C}_{3} \mathrm{~F}_{7}$ substituted 2,6-dipyrazolyl pyridine ancillary, TF- $t \mathrm{Bu}_{-} \mathrm{C}_{3} \mathrm{~F}_{7}$ sensitizer was mass produced to allow the fabrication of DSC module, which showed an active-area of $11.2 \mathrm{~cm}^{2}$ and overall performances of $J_{\mathrm{SC}}=18.51 \mathrm{~mA} \mathrm{~cm}{ }^{-2}, V_{\mathrm{OC}}$ $=737 \mathrm{mV}, \mathrm{FF}=0.55$ and $\mathrm{PCE}=7.55 \%$ under simulated one sun irradiation. Upon placed under indoor lighting (T5 lamp), it showed an improved PCE of $\mathbf{1 2 . 7 0 \%}$ due to the better spectral matching between sensitizer and illumination source. Hence, the gained experiences should be of valuable to the future application of DSC devices.

\section{Experimental section}

\section{Device fabrication}

The pre-cleaned FTO glasses ( $4 \mathrm{~mm}$ thickness, Nippon Sheet Glass Co., Japan) were immersed in a $40 \mathrm{mM}$ aqueous $\mathrm{TiCl}_{4}$ solution at $75^{\circ} \mathrm{C}$ for $30 \mathrm{~min}$, followed by washing with water and ethanol. They were then deposited with $15 \mu \mathrm{m}$ of $20 \mathrm{~nm} \mathrm{TiO}_{2}$ particles, followed by a $5 \mu \mathrm{m}$ scattering layer containing $400 \mathrm{~nm}$ $\mathrm{TiO}_{2}$ particles (PST-400, JGC Catalysts and Chemicals, Japan). The $\mathrm{TiO}_{2}$ electrodes were heated in air at $325{ }^{\circ} \mathrm{C}$ for $30 \mathrm{~min}$, followed by heating at $375{ }^{\circ} \mathrm{C}$ for $5 \mathrm{~min}, 450{ }^{\circ} \mathrm{C}$ for $15 \mathrm{~min}$, and $500{ }^{\circ} \mathrm{C}$ for $30 \mathrm{~min}$. They were next treated with $40 \mathrm{mM}$ aqueous solution of $\mathrm{TiCl}_{4}$ for $30 \mathrm{~min}$ at $75{ }^{\circ} \mathrm{C}$, followed by heating at $500{ }^{\circ} \mathrm{C}$ for $30 \mathrm{~min}$. Subsequently, these $\mathrm{TiO}_{2}$ films were immersed in a dye solution for $18 \mathrm{~h}$ at $25^{\circ} \mathrm{C}$. The dye solution contained $0.3 \mathrm{mM}$ of each sensitizer in 1-propanol, along with
$0.6 \mathrm{mM}$ of tetra-butylammonium deoxycholate [TBA][DOC], and $0.3 \mathrm{mM}$ of each sensitizer contained the $20 \%$ DMSO in ethanol.

\section{Procedures for device measurement}

Photovoltaic measurements were tested under a class-AAA solar simulator (Model 11016A, Sun 3000, ABET Technologies) equipped with a $550 \mathrm{~W}$ xenon light source and water-cooling stage $\left(25^{\circ} \mathrm{C}\right)$. The current-voltage characteristic of each cell was obtained using a Keithley digital source meter (Model 2400). The spectra of incident photon-to-current conversion efficiency (IPCE) were calculated with the equation of $1240 J_{\mathrm{SC}}(\lambda) /\left(\lambda P_{\text {in }}(\lambda)\right)$ where $J_{\mathrm{SC}}$ is the short-circuit current density under each monochromatic illumination in unit of $\mathrm{A} \mathrm{cm}^{-2}, \lambda$ is the wavelength of incident monochromatic light in unit of nanometer, and $P_{\text {in }}$ is the monochromatic light intensity in unit of $\mathrm{W} \mathrm{cm} \mathrm{cm}^{-2}$. 10 values of $J_{\mathrm{SC}}$ (interval $50 \mathrm{~ms}$ ) were collected sequentially after illuminating the device for 3 seconds and then averaged for calculation of IPCE. A $300 \mathrm{~W}$ Xe lamp (Model 6258, Newport Oriel) combined with an Oriel cornerstone 260 1/4 m monochromator (Model 74100) provided a device under test with a monochromatic beam (DC mode). The beam power intensity was calibrated with a power meter (Model 1936C, Newport) equipped with a Newport 818-UV photodetector.

\section{Photophysical measurements of DSC devices}

Charge extraction (CE) was measured with the PGSTAT302N electrochemical workstation (Autolab) at an open-circuit condition for the photovoltage of the device to attain a steady state. The red light-emitting diode (LED, $627 \mathrm{~nm}$ ) was switched off while the device was simultaneously switched to a shortcircuit condition to measure the excess charges generated in the film. Intensity-modulated photovoltage spectroscopy (IMVS) measurement was conducted using the same electrochemical workstation equipped with a frequency response analyzer (FRA) to drive a red light emitting diode. The analysis of the photovoltage response of the cells was conducted in the frequency range of $10^{4}$ to $1 \mathrm{~Hz}$ and LED supplied the AC (modulation depth $10 \%$ ) perturbation current superimposed on the DC current.

\section{Device performance measured under indoor illumination}

This system is composed of a standardized T5 fluorescent lamp (FH14D-EX/T, China Electric Mfg Corporation, Taiwan) or a LED light source (FOP/A/40W/757/U/2 $\times 2$, Everlight, Taiwan), of which both are mounted on the motor-controlled vertical tracks. The setup is equipped with a calibrated spectroradiometer (ISM-Lux, Isuzu Optics, Japan), and selective levels of illumination are achieved by changing the relatively height of T5 or LED lamp $v s$. the spectroradiometer (or DSC cells). The $J-V$ curves were recorded with a computer-controlled digital source meter (Keithley 2400C, USA) at various indoor lighting conditions. ${ }^{64,65}$

\section{Conflicts of interest}

There are no conflicts of interest. 


\section{References}

1 S. Zhang, X. Yang, Y. Numata and L. Han, Energy Environ. Sci., 2013, 6, 1443-1464.

2 T. M. Brown, F. De Rossi, F. Di Giacomo, G. Mincuzzi, V. Zardetto, A. Reale and A. Di Carlo, J. Mater. Chem. A, 2014, 2, 10788-10817.

3 Y. Bai, I. Mora-Seró, F. De Angelis, J. Bisquert and P. Wang, Chem. Rev., 2014, 114, 10095-10130.

4 K. G. Reddy, T. G. Deepak, G. S. Anjusree, S. Thomas, S. Vadukumpully, K. R. V. Subramanian, S. V. Nair and A. S. Nair, Phys. Chem. Chem. Phys., 2014, 16, 6838-6858.

5 M.-E. Ragoussi and T. Torres, Chem. Commun., 2015, 51, 3957-3972.

6 B. Pashaei, H. Shahroosvand, M. Graetzel and M. K. Nazeeruddin, Chem. Rev., 2016, 116, 9485-9564.

7 M. Pazoki, U. B. Cappel, E. M. J. Johansson, A. Hagfeldt and G. Boschloo, Energy Environ. Sci., 2017, 10, 672-709.

8 L. Zhang and J. M. Cole, ACS Appl. Mater. Interfaces, 2015, 7, 3427-3455.

9 J. Wu, Z. Lan, J. Lin, M. Huang, Y. Huang, L. Fan and G. Luo, Chem. Rev., 2015, 115, 2136-2173.

10 S. Thomas, T. G. Deepak, G. S. Anjusree, T. A. Arun, S. V. Nair and A. S. Nair, J. Mater. Chem. A, 2014, 2, 4474-4490.

11 G. C. Vougioukalakis, A. I. Philippopoulos, T. Stergiopoulos and P. Falaras, Coord. Chem. Rev., 2011, 255, 2602-2621.

12 P. G. Bomben, K. C. D. Robson, B. D. Koivisto and C. P. Berlinguette, Coord. Chem. Rev., 2012, 256, 1438-1450.

13 Y. Chi, B. Tong and P.-T. Chou, Coord. Chem. Rev., 2014, 281, 1-25.

14 Y. Chi, K.-L. Wu and T.-C. Wei, Chem.-Asian J., 2015, 10, 1098-1115.

15 L.-L. Li and E. W.-G. Diau, Chem. Soc. Rev., 2013, 42, 291-304.

16 T. Higashino and H. Imahori, Dalton Trans., 2015, 44, 448463.

17 S. Mathew, A. Yella, P. Gao, R. Humphry-Baker, F. E. CurchodBasile, N. Ashari-Astani, I. Tavernelli, U. Rothlisberger, M. K. Nazeeruddin and M. Grätzel, Nat. Chem., 2014, 6, 242-247.

18 Z. Yao, M. Zhang, R. Li, L. Yang, Y. Qiao and P. Wang, Angew. Chem., Int. Ed., 2015, 54, 5994-5998.

19 S. Ahmad, E. Guillen, L. Kavan, M. Gratzel and M. K. Nazeeruddin, Energy Environ. Sci., 2013, 6, 3439-3466. 20 Y. Wu and W. Zhu, Chem. Soc. Rev., 2013, 42, 2039-2058.

21 S. Chen, L. Yang, J. Zhang, Y. Yuan, X. Dong and P. Wang, ACS Photonics, 2017, 4, 165-173.

22 Y. Ren, J. Liu, A. Zheng, X. Dong and P. Wang, Adv. Sci., 2017, 4, 1700099.

23 J.-F. Yin, M. Velayudham, D. Bhattacharya, H.-C. Lin and K.-L. Lu, Coord. Chem. Rev., 2012, 256, 3008-3035.

24 G. Koyyada, V. Botla, S. Thogiti, G. Wu, J. Li, X. Fang, F. Kong, S. Dai, N. Surukonti, B. Kotamarthi and C. Malapaka, Dalton Trans., 2014, 43, 14992-15003.

25 W.-C. Chen, F.-T. Kong, Z.-Q. Li, J.-H. Pan, X.-P. Liu, F.-L. Guo, L. Zhou, Y. Huang, T. Yu and S.-Y. Dai, ACS Appl. Mater. Interfaces, 2016, 8, 19410-19417.
26 L. Han, A. Islam, H. Chen, C. Malapaka, B. Chiranjeevi, S. Zhang, X. Yang and M. Yanagida, Energy Environ. Sci., 2012, 5, 6057-6060.

27 H. Ozawa, Y. Okuyama and H. Arakawa, ChemPhysChem, 2014, 15, 1201-1206.

28 S.-W. Wang, C.-C. Chou, F.-C. Hu, K.-L. Wu, Y. Chi, J. N. Clifford, E. J. Palomares, S.-H. Liu, P.-T. Chou, T. C. Wei and T. Y. Hsiao, J. Mater. Chem. A, 2014, 2, 17618-17627.

29 Y. Numata, S. P. Singh, A. Islam, M. Iwamura, A. Imai, K. Nozaki and L. Han, Adv. Funct. Mater., 2013, 23, 18171823.

30 C.-W. Hsu, S.-T. Ho, K.-L. Wu, Y. Chi, S.-H. Liu and P.-T. Chou, Energy Environ. Sci., 2012, 5, 7549-7554.

31 D. G. Brown, P. A. Schauer, J. Borau-Garcia, B. R. Fancy and C. P. Berlinguette, J. Am. Chem. Soc., 2013, 135, 1692-1695.

32 B. Schulze, D. G. Brown, K. C. D. Robson, C. Friebe, M. Jäger, E. Birckner, C. P. Berlinguette and U. S. Schubert, Chem.Eur. J., 2013, 19, 14171-14180.

33 G. Wu, R. Kaneko, K. Sugawa, A. Islam, I. Bedja, R. K. Gupta, L. Han and J. Otsuki, Dyes Pigm., 2017, 140, 354-362.

34 Y. Chi, T.-K. Chang, P. Ganesan and P. Rajakannu, Coord. Chem. Rev., 2017, 346, 91-100.

35 M. Hussain, A. Islam, I. Bedja, R. K. Gupta, L. Han and A. El-Shafei, Phys. Chem. Chem. Phys., 2014, 16, 14874-14881. 36 G. Li, A. Yella, D. G. Brown, S. I. Gorelsky, M. K. Nazeeruddin, M. Grätzel, C. P. Berlinguette and M. Shatruk, Inorg. Chem., 2014, 53, 5417-5419.

37 M. Urbani, M. Medel, S. A. Kumar, M. Ince, A. N. Bhaskarwar, D. González-Rodríguez, M. Grätzel, M. K. Nazeeruddin and T. Torres, Chem.-Eur. J., 2015, 21, 16252-16265.

38 L. E. Polander, A. Yella, B. F. E. Curchod, A. N. Ashari, J. Teuscher, R. Scopelliti, P. Gao, S. Mathew, J.-E. Moser, I. Tavernelli, U. Rothlisberger, M. Gratzel, M. K. Nazeeruddin and J. Frey, Angew. Chem., Int. Ed., 2013, 52, 8731-8735.

39 G. Li, K. Hu, K. C. D. Robson, S. I. Gorelsky, G. J. Meyer, C. P. Berlinguette and M. Shatruk, Chem.-Eur. J., 2015, 21, 2173-2181.

40 J.-Y. Li, C. Lee, C.-Y. Chen, W.-L. Lee, R. Ma and C.-G. Wu, Inorg. Chem., 2015, 54, 10483-10489.

41 A. Colombo, C. Dragonetti, M. Magni, D. Meroni, R. Ugo, G. Marotta, M. Grazia Lobello, P. Salvatori and F. De Angelis, Dalton Trans., 2015, 44, 11788-11796.

42 S. Inoue, H. Minemawari, J. Y. Tsutsumi, M. Chikamatsu, T. Yamada, S. Horiuchi, M. Tanaka, R. Kumai, M. Yoneya and T. Hasegawa, Chem. Mater., 2015, 27, 3809-3812.

43 S. Maniam, A. B. Holmes, G. A. Leeke, A. Bilic and G. E. Collis, Org. Lett., 2015, 17, 4022-4025.

44 K.-L. Wu, W.-P. Ku, J. N. Clifford, E. Palomares, S.-T. Ho, Y. Chi, S.-H. Liu, P.-T. Chou, M. K. Nazeeruddin and M. Grätzel, Energy Environ. Sci., 2013, 6, 859-870.

45 C.-C. Chou, F.-C. Hu, H.-H. Yeh, H.-P. Wu, Y. Chi, J. N. Clifford, E. Palomares, S.-H. Liu, P.-T. Chou and G.-H. Lee, Angew. Chem., Int. Ed., 2014, 53, 178-183. 
46 H.-Y. Ku, B. Tong, Y. Chi, H.-C. Kao, C.-C. Yeh, C.-H. Chang and G.-H. Lee, Dalton Trans., 2015, 44, 8552-8563.

47 S.-H. Yang, K.-L. Wu, Y. Chi, Y.-M. Cheng and P.-T. Chou, Angew. Chem., Int. Ed., 2011, 50, 8270-8274.

48 K.-L. Wu, S.-T. Ho, C.-C. Chou, Y.-C. Chang, H.-A. Pan, Y. Chi and P.-T. Chou, Angew. Chem., Int. Ed., 2012, 51, 5642-5646.

49 V. S. Manthou, E. K. Pefkianakis, P. Falaras and G. C. Vougioukalakis, ChemSusChem, 2015, 8, 588-599.

50 Z. Zhang, S. M. Zakeeruddin, B. C. O'Regan, R. HumphryBaker and M. Grätzel, J. Phys. Chem. B, 2005, 109, 2181821824.

51 D. P. Hagberg, J.-H. Yum, H. Lee, F. De Angelis, T. Marinado, K. M. Karlsson, R. Humphry-Baker, L. Sun, A. Hagfeldt, M. Grätzel and M. K. Nazeeruddin, J. Am. Chem. Soc., 2008, 130, 6259-6266.

52 B. C. O'Regan and J. R. Durrant, Acc. Chem. Res., 2009, 42, 1799-1808.

53 B. C. O'Regan, K. Walley, M. Juozapavicius, A. Anderson, F. Matar, T. Ghaddar, S. M. Zakeeruddin, C. Klein and J. R. Durrant, J. Am. Chem. Soc., 2009, 131, 3541-3548.

54 J. N. Clifford, E. Martinez-Ferrero and E. Palomares, J. Mater. Chem., 2012, 22, 12415-12422.

55 Q. Wang, S. Ito, M. Grätzel, F. Fabregat-Santiago, I. MoraSeró, J. Bisquert and T. Bessho, J. Phys. Chem. B, 2006, 110, 25210-25221.
56 N. Karjule, M. K. Munavvar Fairoos and N. Jayaraj, J. Mater. Chem. A, 2016, 4, 18910-18921.

57 Q. Wang, J.-E. Moser and M. Grätzel, J. Phys. Chem. B, 2005, 109, 14945-14953.

58 N. Giovambattista, P. G. Debenedetti and P. J. Rossky, J. Phys. Chem. B, 2007, 111, 9581-9587.

59 V. Leandri, H. Ellis, E. Gabrielsson, L. Sun, G. Boschloo and A. Hagfeldt, Phys. Chem. Chem. Phys., 2014, 16, 19964-19971.

60 H. Zhang, L. Qiu, D. Xu, W. Zhang and F. Yan, J. Mater. Chem. A, 2014, 2, 2221-2226.

61 D. Kuang, C. Klein, S. Ito, J.-E. Moser, R. Humphry-Baker, N. Evans, F. Duriaux, C. Grätzel, S. M. Zakeeruddin and M. Grätzel, Adv. Mater., 2007, 19, 1133-1137.

62 T.-K. Chang, H. Li, K.-T. Chen, Y.-C. Tsai, Y. Chi, T.-Y. Hsiao and J.-J. Kai, J. Mater. Chem. A, 2015, 3, 18422-18431.

63 M. Freitag, J. Teuscher, Y. Saygili, X. Zhang, F. Giordano, P. Liska, J. Hua, S. M. Zakeeruddin, J.-E. Moser, M. Grätzel and A. Hagfeldt, Nat. Photonics, 2017, 11, 372-378.

64 Y.-C. Liu, H.-H. Chou, F.-Y. Ho, H.-J. Wei, T.-C. Wei and C.-Y. Yeh, J. Mater. Chem. A, 2016, 4, 11878-11887.

65 C.-L. Wang, P.-T. Lin, Y.-F. Wang, C.-W. Chang, B.-Z. Lin, H.-H. Kuo, C.-W. Hsu, S.-H. Tu and C.-Y. Lin, J. Phys. Chem. C, 2015, 119, 24282-24289. 